\title{
COLLABORATION BETWEEN LOWERSILESIAN CULTURAL TOURISM ATTRACTIONS - A REALITY OR A DREAM OF A FUTURE?
}

\author{
MARTA DROZDOWSKA, ${ }^{1}$ MAGDALENA DUDA-SEIFERT, ${ }^{2}$ \\ MAŁGORZATA LEŚNIAK-JOHANN ${ }^{3}$
}

${ }^{1}$ Szkoła Główna Turystyki i Rekreacji w Warszawie, POLAND

e-mail: marta.drozdowska@handlowa.eu

${ }^{2}$ Uniwersytet Wrocławski, POLAND

e-mail: magdalena.duda-seifert@uwr.edu.pl

${ }^{3}$ Wyższa Szkoła Handlowa we Wrocławiu, POLAND

e-mail: malgorzata.lesniak@handlowa.eu

KEYWORDS | collaborative strategies, interorganisational cooperation, heritage tourism attractions

ABSTRACT

Interorganisational cooperation seems to have become the common strategy in a modern tourism market. On one hand it strengthens organisations with all the benefits it can offer, on the other it develops and promotes the competitive advantage of a destination on a global tourist market. The paper focuses on cultural tourism attractions sector in Lower Silesia region in Poland. It sets out to identify various forms of the collaboration and follows with analysing two different cases of them. They are furthermore compared which allows to draw conclusions concerning both the benefits and weaknesses of both. Final results include assumptions of the authors concerning the conditions for succesful collaboration in case of heritage tourism attractions.

\section{Introduction}

The idea of collaboration used to be employed by industrial businesses, however these are especially ,tourism planners and operators (who) are discovering the power of collaborative action" (Selin, 1993, p. 18). Its more relevant in case of common promotion of a destination than the traditional microeconomic model of competition which is not applicable in such a case (Jacson, Murphy, 2006, p. 118). According to many authors, these collaborative relationships are vital in the tourism 
sector especially because of its fragmented and interdependent nature (Fyall, Leask, Garrod, 2001; Murphy, 1997; Nordin, 2003; Novelli, Schmitz, Spencer, 2006). It is however the tourist attraction that plays a core role in attracting tourists and shaping the appeal of the destination. It has a power of representing and delivering the particular sense of place that provides the basis for competition between destinations (Middleton, Clarke, 2001). For the purposes of the paper a tourism attraction is understood as a place, ,which sets out to attract visitors and is managed accordingly, provides a fun and pleasurable experience and an enjoyable way for customers to spend their leisure time" (Walsh-Heron, Stevens, 1990, p. 2). It becomes the part of cultural tourism while offering the type of activity through which tourists may learn about, witness or experience the cultural heritage of a destination, incorporating places such as museums, historical sites, buildings, and monuments (Williams, 1998). The attraction can belong to one of three sectors depending on its ownership, which are private, public or non-government one.

A variety of terms are used to describe different collaborative arrangements in tourism, including coalitions, forums, alliances, task forces and public-private partnerships (Bramwell, Lane, 2000), but also clusters and networks (Farsani, Coelho, Costa, 2014; Nordin, 2003; Novelli et al., 2006).

Case studies analysed below examine how collaborations can be built and maintain in tourism. Hence the research focuses on the conditions for building the relationship that is really long-lasting and has the effect on the development of a tourist destination. This paper sets out to analyse the forms of collaborative strategies which can be adapted by cultural visitor attractions. So, first the notion of collaboration is discussed together with its different forms and benefits provided. The differing approaches to collaborative strategies are analysed which sets the basis for the procedure of research upon collaborations in tourism. Finally, two case studies are discussed within the frames of features proposed and the conclusions are drawn based on the comparison between these two examples. The research was conducted from December of 2015 to February of 2016, based on secondary data, completed by interviews.

\section{Collaboration and its forms in tourism}

According to Wood and Gray (1991, p. 146), “Collaboration occurs when a group of autonomous stakeholders of a problem domain engage in an interactive process, using shared rules, norms and structures, to act or decide on issues related to that domain". Five key characteristics of the collaboration proces were outlined by Gray such as: the stakeholders are independent; solutions emerge by dealing constructively with differences; joint ownership of decisions is involved; the stakeholders assume collective responsibility for the ongoing direction of the domain and collaboration is an emergent process where collaborative initiatives are ,emergent organisational arrangements through which organisations collectively cope with the growing complexity of their environments" (1989, p. 236). While the term collaboration is commonly used in the academic tourism literature, in government and practitioner circles the term partnerships is popular, and these embrace many collaborative forms. Collaborative interaction is considered to involve face-to-face dialogue, and this 
is a feature distinguishing it from some other types of participation in policy-making (Carr et al., 1998 cited after Bramwell and Lane, 2000). Although collaborative planning interpretations have been criticised, they answer the reality of increasing neo-liberal public management philosophies where governments are increasingly diminishing their responsibilities (Dredge, 2006). In tourism, the collaborative planning idea has received increasing attention with works of Bramwell and Lane (2000), Bramwell and Sharman (1999), Jamal and Getz (1995) and others.

The most intensive and institutionalised form of collaboration is tourism cluster, which constitutes an array of linked industries and other entities in competition, providing complementary products, such as accommodation, attractions and retail outlets. Although they exist in the market independently, it is thanks to collaboration that they not only add value to themselves but also provide a final holistic tourist experience, usually in the form of a package. This is why this structure has gained the term of 'diagonal cluster' (Michael, 2003; Staszewska, 2009; Wang, Fesenmaier, 2007). Clusters are usually located around tourist assets whereas the key factor in their development is the scope of stakeholders which should encompass local authorities, supporting institutions, scientific and research institutions with local small and medium enterprises (BorkowskaNiszczota, 2015a).

The last term to be mentioned is network. However, one of basic differences between cluster and network is that networks can occur among firms situated anywhere, whereas clusters usually refer to a core of firms in a more limited geographical area (Farsani et al. 2014; Nordin 2003).

Wood and Gray's (1991) definition of collaboration is especially useful as it encompasses the diversity of partnership forms in tourism planning that are found in practice. There is, therefore, a whole range of different solutions that can be analysed and compared. For example, the definition makes no assumptions about the scope and nature of the issue or problem domain which means that these tourism-related issues can be either broad and strategic or focused on specific concern. The intended outcomes of collaborative arrangements can also differ, with the objective sometimes being to develop a strategic vision or a plan for a destination, and in other cases to implement some practical measures. The definition also makes no assumptions about which stakeholders will participate, how much power they may have, how representative they may be, or about the total number of stakeholders that are involved ${ }^{1}$. Are there participants from government, business and non-profit sectors, and from national, regional and local policy arenas? (Bramwell, Lane, 2000). In that respect, analysis can regard: form of initiation, the structure and size, involvement of coordinator, the number of horizontally related sectors. Further, the definition does not limit their duration or time-scale nor the intensity of relations, although collaborative processes usually require at least several interactions (Bramwell, Lane, 2000). The collaboration may cover different forms and these activities can also become the point of analysis. The activities or domains within collaborative strategy can include 5 basic formulas which are: the attraction product and visitor management (coordination of strategies, innovative thematic packages, joint activities and events); pricing and

\footnotetext{
${ }^{1}$ E.g. a study of participants in tourism and outdoor recreation alliance in the United States found that they mentioned the diversity of the participating stakeholders as a factor in the alliance's effectiveness (Selin, Myers, 1998, cited after Selin, 1999).
} 
revenue generation (joint ticketing, joint bying from suppliers, caterers and print agents); promotion (collaborative advertising, branding, joint development of Internet web-sites); distribution and booking channels and research staff (collaborative research studies, share information and benchmark attractions) (Fyall et al., 2001).

Additional points made by Borkowska-Niszczota (2015a) which can be analysed in order to differentiate and classify those alliances are: source of funding at the early stage of development, organisational and legal form of activity, phase or cycle of life. Some research follows the idea that the tourism partnerships evolve over time, e.g. Jamal and Getz (1995) propose a three-stage model, including problem setting (identifying key stakeholders and issues), direction setting (identifying and sharing future collaborative interpretations; appreciating a sense of common purpose) and implementation (putting the resulting policies into practice, monitoring progress and ensuring compliance with collaborative decisions), which may or may not be required, depending on the nature and objective of the collaboration (1995).

The difficult task arises of how to evaluate the success of a partnership since it can be done on a number of levels. According to Long and Arnold (1995, cited by Bramwell and Lane, 2000) it can be done on at least three levels. First, against the goals: did the partnership accomplish its objective? Second, in relation to indirect benefits: are there other benefits not directly related to the central issue (e.g. job creation)? And, third, in relation to the processes of collaborative working: how well did the process of partnering work?

\section{The benefits of collaboration in tourism}

The main reasons for collaboration are as follows: counteracting the negative competition effects on a given market, reduction of costs of actions undertaken, the common use of resources. Collaboration allows to supplement resources and competencies with those held by other market participants (suppliers, customers, competitors), thus increasing the competitiveness of the exchange partners, both at a given moment and in the longer term (Gardzińska, 2012). In this regard the mutual dependence of internal (for entities forming a cluster) and external (for the region) benefits seems important. The internal processes such as improving quality of tourism services, generating innovation, developing and marketing new services and goods can strengthen the tourist attractiveness of the region (Borkowska-Niszczota, 2015b). Synergy is a major generator of added value in tourism, i.e. formation of extra quality which is not a sum of values contributed by individual stakeholders of regional tourism economy (Bednarczyk, 2014). E.g. clustering may enhance the growth of market size, employment and product and in context of tourism may create a localised chain whereby a sub-products 'produce' the overall tourism product. Therefore, the clustering brings benefits for both the region and tourism enterprises themselves (Firley, Rożek, 2012) (Figure 1).

Strong competitive position of clusters may be associated with the creation of common strategy as the basis for further action, eg. marketing, brand building, creating a corporate identity and ensuring an attractive form of advertising. As a result, regions are better recognized and acquire new customers (Sikora, 2012). Furthemore, the cluster can produce an effect of cumulative 


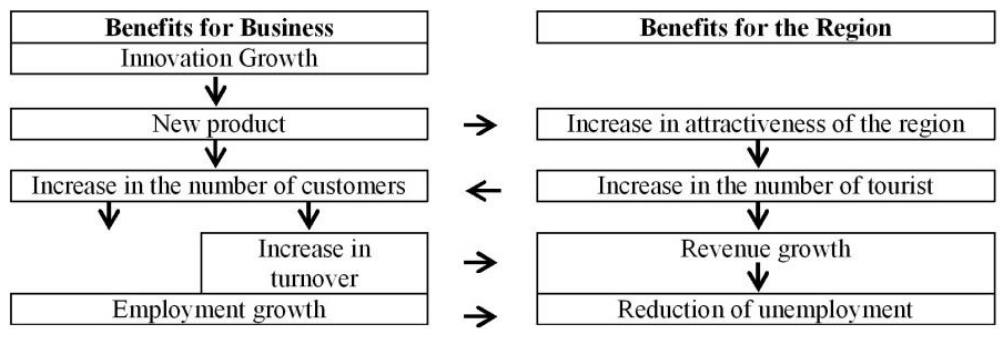

Figure 1. Benefits that result from the cluster's operation

Source: Kusa, Peszko (2006), p. 182.

attraction, which describes relationships of appeal between attractions. These relations are stronger if the individual attractions are dissimilar, however, still complement each other with their theme (Weidenfeld et al., 2010). Within destinations compatibility between attractions, which is the measure of the effect that one business has upon an adjacent or proximate business (the degree to which businesses interchange customers) is an essential element for sustaining their appeal and contributes to a destination's unique character (Fyall et al., 2001).

\section{Case studlies}

Recently, increasing opportunities for socio-economic development of Polish tourist regions have become more dependant on collaboration of actors who create regional tourist product. Therefore, varied forms of collaboration such as local/regional tourist organizations, local action groups, partnerships, clusters or the like have been gaining increasing popularity.

Two examples of collaboration in tourism have been selected on the basis of the research through the secondary data. Both developed within the territory of Lower Silesia region. Majority of reports places this region high among Polish voivodeships based on its competitiveness, attractiveness for investors, entrepreneurship indicator as well as on its innovative potential (Kocowska, 2007; Majewski, 2007; Szostak 2010). Lower Silesia has already entered European ERRIN network, it also disposes of Regional Strategy of Innovation, and uses the Structural Funds. It also belongs to the top three most attractive touristically Polish regions (Bąk and Matlegiewicz, 2010). It is also a third most frequently visited region in Poland ${ }^{2}$. The localisation near borders with Germany and Czech Republic makes it easily accessible for incoming tourists. It is tourism that is cited as one of two main priorities for development of Lower Silesia in the horizon of 2020 based on its high potential of natural, cultural and spa attractions (Nowa Strategia..., 2013). Additionally, according to the research, the understanding of importance of tourism in the Lowersilesian subregions has been growing in recent years together with the knowledge of how to build linear tourist products based on collaboration of local governments and tourist businesses (Fedyk, Dołęga, 2009).

\footnotetext{
${ }^{2}$ After Mazovieckie and Malopolskie, with 2,416 mill of arrivals at tourist accommodation establishments with 510 thousands of non-residents in 2014 (www.stat.gov.pl).
} 
According to Polish Tourist Organisation the priority aspects of Lowersilesian voivodeship tourism development are: city breaks, cultural tourism, leisure in mountainous areas and business tourism (Potencjat i gradacja..., 2008). Two first mentioned -above forms of tourism have been selected as research themes by authors, therefore two heterodox examples each representing one of them have been studied.

\section{Tourist card in Wroclaw}

Tourist city card concept has been gaining a growing popularity among tourist destinations worldwide. The main reason for collaboration of entities who create such tourist product is the synergy effect in order to create new tourism offer, more efficient promotion and distribution, better management and monitoring of tourism traffic. From the attraction providers point of view it encourages visitors to visit more venues than they might otherwise do and reduces negative effects of a competition on a given market. The value and premises of tourist passes varies from one city to another. Once a city-card programme is set up, the income from sales is pooled between the participating actors in a complex calculation involving visitor numbers, admission prices and prevailing public-transport fares. On the other hand, most city cards provide visitors with wide range of advantages, such as: reduction of their expenditures (free or discounted admission to attractions, reduced public transport tariffs, discounts at shops, accommodation establishments, cafes and restaurants, etc.); flexible operation time adjusted to typical duration of visitor stay in the city (mainly from one to three days); more intense experience; priority access (with a city card visitors can jump the line); free sightseeing souvenirs (e.g. guidebook or map). As a result, cities gain better recognition and acquire new visitors.

Tourist cards, with different success, are available in big Polish cities such as: Cracow (krakowcard.com), Warsaw (warsawpass.com), Tri-City (gdansk4u.pl/kartaturysty) or Poznan (poznan. travel/pl/c/poznanska-karta-turystyczna). Wroclaw however, third most popular tourist destination in Poland ${ }^{3}$ with over one million of tourists in 2014 (30\% non-residents) doesn't offer tourist card, although it had a try in establishing tourist pass, named OpenWroclaw while being one of the host cities for EURO 2012, so the 14th European Championship for men's national football teams organised by UEFA (Table 1).

City spent 2,5 million PLN in order to establish OpenWroclaw. 150 thousands of cards were planned to be distributed in the beginning, but only 550 cards were sold. Finally none of the goals were achieved and the project was closed. Despite well-recognized and well-functioning in many cities worldwide product of a tourist pass, high tourist potential of Wrocław, clear benefits of such collaboration and confirmations of representatives of City Council of Wroclaw that the tourist card will be renewed, the city still doesn't offer tourist pass.

\footnotetext{
${ }^{3}$ After Warsaw (3,068 mill) and Cracow (2,284 mill) (www.stat.gov.pl).
} 
Tabble 1. Collaboration characteristics of OpenWroclaw

\begin{tabular}{|c|c|}
\hline Collaboration characteristic & $\begin{array}{l}\text { Tourist card in Wroclaw } \\
\text { (premises) }\end{array}$ \\
\hline Initiator & City of Wroclaw \\
\hline Leader & Forum Medicum Association (winning the tender for tourist pass implementation) \\
\hline Stakeholders & $\begin{array}{l}\text { As a target: } 130 \text { tourist attractions; } 250 \text { accommodation, food and beverage establishments; } 250 \\
\text { branded distribution points; Info Points network }\end{array}$ \\
\hline $\begin{array}{l}\text { Nature of the issue } \\
\text { or problem domain }\end{array}$ & $\begin{array}{l}\text { Creation of integrated product dedicated to residents and tourists, making travel through the city more } \\
\text { efficient and improving accessibility of cultural, sport and recreation facilities }\end{array}$ \\
\hline Intended outcomes & $\begin{array}{l}\text { Using the chance of increased tourist traffic during Euro, integration of Wroclaw's entities engaged } \\
\text { in tourism sector }\end{array}$ \\
\hline Activities or domains & $\begin{array}{l}\text { The attraction (both product and visitor) management - innovative thematic packages; pricing and rev- } \\
\text { enue generation - joint ticketing; joint distribution and booking channels }\end{array}$ \\
\hline Sectors of stakeholders & $\begin{array}{l}\text { Participants from government, business and non-profit sectors, and from national, regional and local } \\
\text { policy arenas }\end{array}$ \\
\hline Type of the destination & City, well developed and long-established international tourist destination \\
\hline Volume of the tourist traffic & 1,010 million of tourists ( 310 thousands of non-residents) (in 2014) \\
\hline Duration & Started: in May 2012, closed in February 2013 \\
\hline
\end{tabular}

Source: own elaboration based on available interviews in local newspapers, OpenWroclaw and Forum Medicum documents.

Table 2. Assumptions and their execution in case the OpenWroclaw project

\begin{tabular}{|c|c|}
\hline Main assumptions & Examples of the execution \\
\hline - Valid for 24,48 or 72 hours & - Particular length of cards was available \\
\hline $\begin{array}{l}\text { - Available in packages: 1) Culture, 2) Culture \& Fun, 3) } \\
\text { Culture, Fun \& Sport }\end{array}$ & - Small difference between offers in different packages \\
\hline - Competitive price & - Too expensive ( $24 \mathrm{~h}$ packets for $58-109 \mathrm{PLN})$ \\
\hline $\begin{array}{l}\text { - Free entrance to } 130 \text { tourist attractions and discount } \\
\text { system in } 250 \text { accommodation and food and beverage } \\
\text { establishments }\end{array}$ & $\begin{array}{l}\text { - Unwieldy system of implementation; less than } 130 \text { agreements } \\
\text { signed, mainly based on discounts, free entrance only to museums } \\
\text { and view points }\end{array}$ \\
\hline - Function of a digital wallet & - The agreement with PKO SA was signed \\
\hline - Integrated with Wroclaw URBANCARD & - Not integrated with Wroclaw URBANCARD \\
\hline - Info Points network & - Only one Info Point in Centennial Hall opened \\
\hline - Card monitoring & - Not implemented \\
\hline - Official www: http://openwroclaw.pl & $\begin{array}{l}\text { - Website neither properly designed, nor translated; even though } \\
\text { Wroclaw planned to renew the idea, the site doesn't work any } \\
\text { longer }\end{array}$ \\
\hline $\begin{array}{l}\text { - As a target } 250 \text { branded distribution points (places of tour- } \\
\text { ist traffic concentration and URBANCARD distribution } \\
\text { points) }\end{array}$ & $\begin{array}{l}\text { - Only } 4 \text { distribution points opened (Aquapark, Centennial Hall, } \\
\text { Airport, Tourist Info in the Market Square); delayed signing of the } \\
\text { agreement; most potential distributors not interested in the project }\end{array}$ \\
\hline $\begin{array}{l}\text { - Participation in the project - paid, dependant on the } \\
\text { number of visitors with the tourist pass in particular tourist } \\
\text { venue }\end{array}$ & - System of payment not fully accomplished (not clear) \\
\hline
\end{tabular}

Source: own elaboration based on available interviews in the local newspapers, OpenWroclaw and Forum Medicum documents.

Therefore, the system of the OpenWrocław has never been fully accomplished and actually was abandoned already at the start of implementation phase (Table 2). On the one hand, lasting not even one year, this example of collaboration didn't have an opportunity to implement the policies 
into practice, but on the other, the mistakes made already in both problem and direction setting were too serious to make it truly efficient.

The authors assume that the OpenWroclaw collaboration failed mainly because the project was directly related to the EURO 2012 and initiated by the city council, which organised the tender, but did not displayed enough attention to the professional qualifications of the winning party, as appropriate for the task to be fulfiled. Second failure was on the side of the leader since the association Forum Medicum wasn’t familiar with tourism business and premises of collaboration among tourist entities ${ }^{4}$. Third problem resulted from the way the project of collaboration was launched, which made it a top-down initiative, which didn't arise from the needs of potential stakeholders, therefore tourist entities weren't motivated to take part in it and didn't see the clear goal for the participation in the project (benefits for individual stakeholders weren't clearly specified). Since the city has already been a long-established destination, the collaboration was probably not perceived as essential for the further existence of individual tourist enterprises on a local market.

\section{Palaces and Gardenns of Jelenia Gora Valley Foundation}

Struggling for customers turns the destination towards forcing its tourist entities to create a unique offer that will not be perceived by tourists as a mass product. The tourist product attracting recently more interest from visitors is cultural tourism (Gryszel, Jaremen, Rapacz, 2010). The Jelenia Gora Valley is an excellent example of cultural tourism potential, with significant aggregation of unique monuments with magnificent historic and cultural value, surrounded by gardens and parks, with impressive scenery of the neighbouring mountains of Karkonosze and Rudawy Janowickie.

In the area of around 100 square kilometers the natural and cultural heritage of Jelenia Gora Valley comprises 27 historic palace or manor and park complexes and other former residential buildings, which belonged to the Dukes of Silesia, royal Prussian Family (Frederick William III and William IV) and most famous aristocratic families (i.a. Radziwill, Czartoryski, Schaffgotsch, Hohenzollern). Neglected, without proper conservation they fell into decay after the Second World War (with few exceptions). It is only recently that they have attracted attention of entrepreneurs and developers after byuing started renovation works transforming those residences into present hotel establishments. Soon, the collaboration between the owners was initiated (Table 3).

The authors distinguish two main types of tourist product development in the region, that are cultural tourism and luxury accommodation establishments. Strict collaboration between tourist entities has concerned especially joined promotion of the region and cultural tourism development (Table 3). Despite the fact that particular entities differ considerably on the ground of their condition (some are luxury hotels, others are in ruin or need a general renovation), ownership status, owners purpose, they collaborate to develop and promote the region as a complex unity. All entities benefit from the economies of scale, branding, knowledge exchange, sharing tourist resources.

\footnotetext{
${ }^{4}$ It was established to integrate, support and develop medical community; e.g. in the application form Forum Medicum used definition of "guest" not "tourist".
} 
Table 3. Collaboration characteristics of Palaces and Gardens of Jelenia Gora Valley Foundation

\begin{tabular}{|c|c|}
\hline $\begin{array}{l}\text { Collaboration } \\
\text { characteristic }\end{array}$ & Palaces and Gardens of Jelenia Gora Valley \\
\hline Initiator & $\begin{array}{l}\text { Historic Landscape Protection Center with dr Andrzej Michalowski as its director at the beginning, later } \\
\text { Institute of National Heritage in Warsaw }\end{array}$ \\
\hline Leader & The Palaces and Gardens of Jelenia Gora Valley Foundation \\
\hline Stakeholders & $\begin{array}{l}\text { Private owners of palaces in the region, public administration, local government, heritage preservation and } \\
\text { conservation authorities, national and foreign associations, science, education and cultural units, entrepre- } \\
\text { neurs etc. }\end{array}$ \\
\hline $\begin{array}{l}\text { Nature of the issue } \\
\text { or problem domain }\end{array}$ & $\begin{array}{l}\text { Conservation and promotion of the historic palace or manor and park complexes and other former residential } \\
\text { buildings in the Jelenia Gora Valley, in particular: conservation and planned land management, promotion } \\
\text { of cultural tourism, spreading the knowledge and idea of conservation and restoration works of local monu- } \\
\text { ments and natural resources, documentation of cultural and natural heritage, development of pro-ecological } \\
\text { attitudes, creation and promotion of local identity and initiatives, research, education and editorial activity }\end{array}$ \\
\hline Intended outcomes & Focused on promotion of the Jelenia Gora Valley as a tourist destination \\
\hline Activities or domains & $\begin{array}{l}\text { - The attraction (both product and visitor) management, conservation of the cultural and natural heritage, } \\
\text { tourism infrastructure development; application „Palaces and Gardens Valley”- mobile guide for mobile } \\
\text { phones, Trail of Palaces and Gardens of Jelenia Gora Valley, revitalization and adaptation for sightseeing } \\
\text { of Palace and Garden in Bukowiec, cultural trail based on natural and cultural heritage on the both sides } \\
\text { of Nysa River; establishing of Culture Park of Jelenia Gora Valley (2008), } 11 \text { of cultural and natural herit- } \\
\text { age actors added to the list of Polish Historic Monuments (2011), attempts to be accepted as a UNESCO } \\
\text { World Heritage Site } \\
\text { - Promotion and popularization of both cultural and natural heritage of the Jelenia Gora Valley through wide } \\
\text { range of festivals, exhibitions, editorial and education undertakings, collaborative advertising, branding, } \\
\text { joint development of Internet web-sites } \\
\text { - Collaborative research studies, share information: e.g. conferences, editorial undertakings }\end{array}$ \\
\hline Type of the destination & $\begin{array}{l}\text { New destination on a tourism market, developed only after change of ownership and mass renovation works } \\
\text { in many of palace and park complexes }\end{array}$ \\
\hline $\begin{array}{l}\text { Volume of the tourist } \\
\text { traffic }\end{array}$ & $\begin{array}{l}99 \text { thousands tourists (including } 9 \text { thousands of non-residents) }{ }^{*} ; 85,5 \text { thousands in Jelenia Gora City ( } 23 \text { thou- } \\
\text { sands of non-residents) (in 2014) }\end{array}$ \\
\hline Duration & Since 2005 , still existing, with promising prospects for future collaboration \\
\hline
\end{tabular}

"According to statistic data for LAU2 in the Jelenia Gora Valley (www.stat.gov.pl).

Source: own elaboration based on http://www.dolinapalacow.pl, https://bdl.stat.gov.pl/BDL, the policy statement of the foundation, reports of the foundation available at: http://bopp.pozytek.gov.pl, http://sprawozdaniaopp.mpips.gov.pl.

Majority of the most important cultural heritage monuments are adapted for accommodation establishments: Bukowiec, Paulinum Palace, Castle in Karpniki, Łomnica Palace, Staniszów, Wojanów. Despite the competition (similar profile of the business activity, close location, same market segment) they decided to bet on collaboration as the paramount goal, which leads to the reduction of the negative competition effects, reduction of costs of collaborative actions taken, the use of resources at the disposal of a partner. Moreover, other heritage sites with different functions (e.g.: Teplice Zdroj palace housing a branch of Wroclaw Technical University; Palace in Myslakowice as both primary and middle school; Palace in Ciszyca, Karpniki Oak Palace or Wojanow -Bobrow Palace as private establishments) enrich and supplement the offer. Beyond the main function of luxury accommodation they offer food and beverage, thematic sightseeing tours through the region (e.g. Local alcohols in Jelenia Gora Valley), geocaching, renting recreation equipment, spa \& wellness, temporary and permanent exhibitions (e.g. Łomnica displays permanent exhibition „Palaces 
and Gardens of Jelenia Gora Valley"), concerts. Some entities established their own foundations (Staniszów, Łomnica). Synergy, collaboration and local identity seems very natural and engaged in the area, Jelenia Gora Valley Foundation should be understood as a good example of famous statement: act local, think global. This collaboration is mainly based on mutual trust between the parties, their joint goal and engagement, strong local leader and opportunities to share good practice. And the synergy effect of collaboration in case of Palaces and Gardens of Jelenia Gora Valley Foundation was essential to bring tourists into the region despite the strong competition of Jelenia Gora, Karkonosze or even Wroclaw.

\section{Conclusions}

Given case studies may lead to further research on the strategies of collaboration in the field of cultural tourism. At this stage, however, we can identify the most important characteristics that can determine the success or failure within the framework of the collaboration undertaken by tourist entities, mainly tourist heritage attractions.

The analysed strategies of collaboration were divided by the following features: the initiator of cooperation, cooperation leader, stakeholders, the way of cooperation initiation and character of cooperation. Essential question was, what strategic actions on cooperation get partners closer to the success on the tourist market and the use of benefits from the synergy effects.

Taking the way for initiating of collaboration into account, the bottom - up approach is more effective (eg. Palaces and Gardens of Jelenia Gora Valley). This approach considers real market needs. Measurable effects of collaboration in the form of market success usually appear in a long time perspective (a few dozen years). Along the way, there appear so called social effects, e.g. greater confidence to partners or greater openness and willingness to take a risk concerning further cooperation. It is therefore essential for creating competitive tourist products. What should not be underestimated are also the synergies arising from the complementarities of goods and services, cooperating entities and joint promotion of tourist products.

Very often there is a trap in initiating collaboration by public authorities, whose main motive is the opportunity to benefit from public funding (eg. EU or national funds). In this case, the so called top-down approach, there are no real market needs and motivations of partners, collaboration turns out to be occasional, and the main theme becomes finances that are "for use" (e.g OpenWrocław).

The main difference between the strategies adopted by tourist entities in two case studies under research is the type of entities engaged. According to theory it seems that common projects that bring together tourist entities from various sectors, focusing on the tourism (cross-sectoral cooperation) should be more effective. However, still the succes depends more on the whole multiplicity of internal and external factors as in case, where despite multi-sectoral collaboration in case of the OpenWrocław Card, project generally ended in failure, but mono-sectoral collaboration in the Palaces and Gardens of Jelenia Gora Valley displays now many signs of success, both for those involved and for the whole tourist destination. Therefore, this is first of all the kind of approach (top- down or down-top) that has got the basic inluence of a succes according to the research. 
The basic question that arises concerns forms of collaboration, which give a chance to succeed in the cultural tourism. There are many forms, however theoretical concepts on this issue do not bring a clear decision. Generally, the phenomenon should be called as a partnership, which may take the different forms, starting from strategic alliances (collaboration in a predetermined purpose), ending with collaboration in clusters as the most institutionalized ones. From the view point of a lasting synergies benefits arising for both tourist entities and for the region, the most welcome form of collaboration is tourism cluster understood as a geographical concentration of entities (tourist and not directly tourist) working together with the aim of tourist destination development. It should be noted that relationships in these clusters do not concern only collaboration but also competition and coopetition, the last one understood as a combination of them two. The benefits of collaboration, however, are much more visible, both in terms of tourism business and the region. It seems that the Palaces and Gardens of Jelenia Gora Valley Foundation, although it still lacks certain features of a cluster, has already developed collaboration in the direction leading towards cluster, which would become the its final and most efficient form.

\section{References}

Bąk, I., Matlegiewicz, M. (2010). Przestrzenne zróżnicowanie atrakcyjności turystycznej województw w Polsce w 2008 roku. Zeszyty Naukowe Uniwersytetu Szczecińskiego, 590, 57-68.

Bednarczyk, M., Wszendybył-Skulska, E. (2014). Synergy as a value generator in tourism. Economic Problems of Tourism, $4(28), 9-21$.

Borkowska-Niszczota, M. (2015a). Tourism Clusters in Eastern Poland - Analysis of Selected Aspects of the Operation. Procedia-Social and Behavioral Sciences, 213, 957-964.

Borkowska-Niszczota, M. (2015b). Wpływ klastrów turystycznych na rozwój i konkurencyjność regionów. Ekonomiczne Problemy Turystyki, 2 (30), 145-164.

Bramwell, B., Lane, B. (2000). Collaboration and Partnerships in Tourism Planning. In: B. Bramwell, B. Lane (eds.), Tourism Collaboration and Partnerships Politics, Practice and Sustainability (pp. 1-19). Clevedon: Channel View Publications.

Bramwell, B., Sharman, A. (1999). Collaboration in local tourism policymaking. Annals of Tourism Research, 26 (2), 392-415.

Dredge, D. (2006). Policy networks and the local organisation of tourism. Tourism Management, 27 (2), $269-280$.

Farsani, N.T., Coelho, C.O.A., Costa, C.M.M. (2014). Analysis of Network Activities in Geoparks as Geotourism Destinations. International Journal of Tourism Research, 16, 1-10.

Fedyk, W., Dołęga, A. (2009). Subregionalne, sieciowe produkty turystyczne Dolnego Śląska. In: J. Marak, J. Wyrzykowski (eds.), Rola turystyki w gospodarce regionu. Tom II: Ustugi turystyczne, jako podstawa gospodarki turystycznej (pp. 180-188). Wrocław: WSH.

Firley, K., Rożek, A. (2012). Korzyści z klasteringu transgranicznego, jako innowacyjnej formy rozwoju usług transgranicznych na obszarach Polski Południowo-Wschodniej. Zeszyty Uniwersytetu Ekonomicznego w Krakowie Ekonomia, 891, 31-50.

Fyall, A., Leask, A., Garrod, B. (2001). Scottish Visitor Attractions: a Collaborative Future? International Journal of Tourism Research, 3, 211-228.

Gardzińska, A. (2012). Coopetition as the Basis for Functioning of Tourism Clasters. Economic Problems of Tourism, 1 (17), 133-145.

Gray, B. (1989). Collaborating: Finding Common Ground for Multiparty Problems. San Francisco: Josey Bas. 
Gray, B. (2000). Assessing Inter-Organizational Collaboration, Multiple Conceptions and Multiple Methods. In: D. Faulkner, M. De Rond (eds.), Cooperative strategy. Economic, Business, and organizational issues (pp. $243-$ 260). New York: Oxford University Press.

Gryszel, P., Jaremen, D.E., Rapacz, A. (2010). Park kulturowy jako stymulator rozwoju turystyki kulturowej. Ekonomiczne Problemy Ustug, 52, 331-340.

Jackson, J., Murphy, P. (2006). Clusters in regional tourism destinations: An Australian case. Annals of Tourism Research, 33 (4), 1018-1035.

Jamal, T.B., Getz, D. (1995). Collaboration theory and community tourism planning. Annals of Tourism Research, 22 (1), 186-204.

Kocowska, B. (2007). Profil innowacyjny Dolnego Śląska. Studia Regionalne i Lokalne, 1 (27), 112-125.

Kusa, R., Peszko, A. (2006). Małopolski klaster turystyczny- perspektywy rozwoju w świetle badań własnych. In: M. Romanowska, P. Wachowiak (eds.), Koncepcje i narzędzia zarządzania strategicznego (pp. 175-184). Warszawa: Szkoła Główna Handlowa. Oficyna Wydawnicza.

Majewski, R. (2007). Konkurencyjność dolnośląskich mikroprzedsiębiorstw na jednolitym rynku europejskim. In: J. Kundera (ed.), Stosunki ekonomiczne w rozszerzonej Unii Europejskiej (pp. 161-174). Cologne: Cologne Limited.

Michael, E.J. (2003). Tourism micro-clusters. Tourism Economics, 9 (2), 133-145.

Middleton, V.T.C., Clarke, J. (2001). Marketing in Travel and Tourism. Oxford: Butterworth-Heinemann.

Murphy, P.E. (ed.) (1997). Quality management in urban tourism. Chichester: John Wiley \& Sons.

Nordin, S. (2003). Tourism Clustering and Innovation - Path to Economic Growth and Development. Ostersund: ETOUR.

Novelli, M., Schmitz, B., Spencer, T. (2006). Networks, clusters and innovation in tourism: a UK experience. Tourism Management, 27, 1141-1152.

Nowa Strategia Rozwoju Województwa Dolnośląskiego 2020 (2013). Urząd Marszałkowski Województwa Dolnośląskiego, Wrocław. Available at: http://www.umwd.dolnyslask.pl/fileadmin/user_upload/Rozwoj_regionalny/SRWD/SRWD _2020-final.pdf(10.02.2016).

Potencjat i gradacja wartości produktów turystycznych województw (2008). Warszawa: POT.

Sikora, K. (2012). Klastry turystyczne szansą rozwoju mikroregionów. Zarządzanie i Finanse, 1 (2), 55-65.

Selin, S. (1993). Collaborative alliances: new interorganizational forms in tourism. Journal of Travel and Tourism Marketing, 2 (2/3), 217-227.

Selin, S. (1999). Developing a Typology of Sustainable Tourism Partnerships. Journal of Sustainable Tourism, 7 (3/4), $260-273$.

Staszewska, J. (2009). Klaster perspektywą dla przedsiębiorców na polskim rynku turystycznym. Warszawa: Difin.

Szostak, E. (2010). Oddziaływanie obszaru metropolitalnego Wrocławia na tworzenie klastrów w regionie. Acta Universitatis Lodziensis, Folia Oeconomica, 246, 169-178.

Walsh-Heron, J., Stevens, T. (1990). The Management of Visitor Attractions and Events. London: Prentice Hall.

Wang, Y., Fesenmaier, D. (2007). Collaborative destination marketing: A case study of Elkhart County, Indiana. Tourism Management, 28, 863-875.

Weidenfeld, A., Butler, R.W., Williams, A.M. (2010). Clustering and Compatibility between Tourism Attractions. International Journal of Tourism Research, 12, 1-16.

Williams S. (1998). Tourism Geography. London: Routledge.

Wood, D., Gray, B. (1991). Toward a comprehensive theory of collaboration. Journal of Applied Behavioral Science, 27 (2), 139-162.

http://bopp.pozytek.gov.pl (23.02.2016).

http://www.dolinapalacow.pl (20.02.2016).

http://sprawozdaniaopp.mpips.gov.pl (23.02.2016).

https://bdl.stat.gov.pl/BDL (10.02.2016).

http://www.umwd.dolnyslask.pl/fileadmin/user_upload/Turystyka/Dokumenty/Badanie_ruchu_turystycznego_na_ Dolnym_Slasku_w_2015_r..pdf(14.02.2016). 


\title{
FORMY WSPÓŁPRACY STOSOWANE PRZEZ KULTUROWE \\ ATRAKCJE TURYSTYCZNE NA DOLNYM ŚLĄSKU \\ - RZECZYWISTOŚĆ CZY MARZENIE PRZYSZŁOŚCI?
}

strategie współpracy, związki partnerskie, atrakcje turystyki kulturowej

STRESZCZENIE

Współpraca między organizacjami staje się nieodzownym elementem funkcjonowania współczesnego sektora usług turystycznych. $\mathrm{Z}$ jednej strony wzmacnia ona same organizacje, $\mathrm{z}$ drugiej pozwala rozwijać i promować konkurencyjne przewagi regionu turystycznego na rynku międzynarodowym. Autorki artykułu określają na bazie literatury możliwe formy takiej współpracy, a następnie analizują dwa wybrane przykłady w odniesieniu do atrakcji turystyki kulturowej na Dolnym Śląsku. Analiza porównawcza pozwala określić słabe i mocne strony każdej z form i może stanowić punkt wyjścia do dalszych badań w celu wskazania rekomendacji dla sektora atrakcji kulturowych w turystyce.
\end{abstract}

